\title{
Eucalyptus globulus bark valorization: Production of fibers by Neutral Sulphite Semi-Chemical Process for Liner Paper Manufacture
}

\author{
Andrea Andrade ${ }^{1,2}$ \\ Orlando Espinoza Herrera ${ }^{1}$ \\ Pablo Reyes-Contreras ${ }^{3,4}$ \\ Miguel Pereira ${ }^{1,2,3}$ \\ Francisco Vásquez-Garay ${ }^{3,4}$ (D)
}

\begin{abstract}
Eucalyptus globulus is the second most important economic forest species in Chile. Its main use is in the kraft pulp industry, where large amounts of bark waste are generated. Due to its fibrous characteristics, E. globulus bark is proposed as an alternative source of fibres for papermaking. This study focuses on obtaining fibres for liner paper manufacture. A neutral sulphite semi-chemical (NSSC) process was performed, varying the sodium sulphite ( $5 \%$ to $16 \%)$ and the sodium carbonate $(2 \%$ and $4 \%)$ concentrations using two reaction temperatures $\left(160^{\circ} \mathrm{C}\right.$ and $\left.170^{\circ} \mathrm{C}\right)$. The NSSC process at $170^{\circ} \mathrm{C}, 16 \%$ of sulphite, and $2 \%$ of sodium carbonate proved to be the best condition to obtain higher mechanical performance of papers. As the pulping conditions become more drastic, the yield drops, and the physicomechanical properties of paper increases. Results showed that pulps from E. globulus bark could turn into source of fibres for papermaking and other related products.
\end{abstract}

Keywords: Biomass valorisation, papermaking, paperboard, NSSC pulping.

\section{INTRODUCTION AND OBJECTIVES}

Eucalyptus is one of the most important tree species for the pulp and paper industry and the specie most widely cultivated in temperate regions (Neiva et al., 2018). It is a fast-growing tree, with a total plantation area between 16-19 million hectares and an annual production of 15-25 ton/ha (Romani et al., 2019). More than $55 \%$ of the current global Eucalyptus production is found in South America. The Chilean forestry industry consumes around 11.9 million $\mathrm{m}^{3}$ of Eucalyptus wood per year, and $53 \%$ is destined for pulp production (ODEPA, 2016).

In the pulp and paper industry, the growing demand for its products, has add extra pressure on the increasingly scarce forest resources, forcing the search for new alternatives for fibre sources. Some alternatives that have been proposed as new raw materials for pulping and paper production are the new fast-growing tree species, annual plants, and residual biomass (Eugenio et al. 2019; Małachowska et al., 2019).

Many companies have considered the use of recycle fibres as an alternative in the pulp and paper industry. Although the use of recycled fibres has environmental and economic benefits, unfortunately, these processes imply the use of heterogeneous material and with several recycling cycles, which generates an intrinsic deterioration of the fibres due to shorter fibre length. Therefore, this could generate an increase in the amount of fines and a low drainability of papers (Rahmaninia and khosravani, 2015; Yang and Berglund, 2020).

In this context, residual biomass from pulp and paper processing has received increasing attention in recent years and may constitute an alternative resource for the extraction of cellulose fibres (Miranda et al., 2013). The advantages of being produced the fibres using residual biomass in the same process decrease the cost of transport and logistics of the supply.

\footnotetext{
${ }^{1}$ Universidad de Concepción (UDEC), Departamento de Ingeniería Química, Laboratorio de Productos Forestales, Concepción, Chile. ${ }^{2}$ Universidad de Concepción (UDEC), Facultad de Ciencias Forestales, Casilla, Concepción, Chile.

${ }^{3}$ Centro de Excelencia en Nanotecnología (CEN), Román Díaz, Providencia, Santiago, Chile.

${ }^{4}$ Leitat Chile, Román Díaz, Providencia, Santiago, Chile.
} 
Therefore, Eucalyptus bark is presented as an interesting raw material for fibre making (Miranda et al., 2012).

Bark represents a substantial proportion of the above ground total biomass of trees, reaching about $10-15 \%$ of the total weight of the tree, and particularly in Eucalyptus globulus specie, it represents around $11 \%$ of the dry weight of the stem (Sartori et al., 2016). Bark has a higher content of extractives and ash than wood (Neiva et al., 2018). Physiologically, tree bark consists mainly of three types of cells-phloem fibres, sieve cells, and phloem parenchyma cells, which are responsible for conducting nutrients along the plant (Matsushita et al., 2010). Bark comprises all the tissues outside of the vascular cambium and represents the outermost layers of the stem and roots of woody plants. It is mainly composed of polysaccharides, lignin, polyphenolics extractives and inorganic materials (Neiva et al., 2018; Sillero et al., 2019). During industrial processing for pulping, bark is removed from the trunks and constitutes an important mill residual material that is usually burned for energy production, contributing to the sustainability of the pulp mill processes (Miranda et al., 2013). 20 tons of bark can be obtained in a pulp mill by 100 tons of pulp processed (Neiva et al., 2018).

Neutral sulphite semi-chemical (NSSC) pulping is a type of semi-chemical pulping process to produce unbleached pulp yields of around $80 \%$, using sodium sulphite as the main cooking agent, buffered with sodium carbonate to maintain a neutral solution (Pereira et al., 2011; Oveissi et al., 2016). The presence of a buffered sodium sulphite cooking solution produces sulphonation and lignin hydrolysis when the cooking time is about 30 minutes at $170-180^{\circ} \mathrm{C}$ (Pereira et al., 2011; Bajpai, 2018). Sulphite pulping like a kraft process, also allows the recycling of chemical agents used, mainly to reduce costs (Neiva et al. 2018). If ultrafiltration membranes were used to recycle filtrate with a high content of sulphite, it would allow a saving of at least $25 \%$ in the cost of reagents (Monsalve et al., 2010).

This research aimed to evaluate the technical feasibility of using E. globulus bark as a source of fibres to produce linertype paper, using an NSSC process. To assess the performance of our proposed method, the raw material and pulp obtained were chemically characterised, as well as the mechanical properties of paper sheets were determined.

\section{MATERIALS AND METHODS}

\subsection{Raw material and preparation}

E. globulus bark was obtained from a 15-year-old commercial tree plantation of a Chilean forest company located in Biobío region (southern Chile). Samples were thoroughly mixed to obtain a single uniform sample and dried at $40^{\circ} \mathrm{C}$ for 24 hours, cut into $2 \times 2 \mathrm{~cm}$ chips and stored in a dry place until used.

\subsection{Chemical characterization of E. globulus bark}

E. globulus bark was milled in a knife mill and sieved to 45-60 mesh. Milled bark was extracted with a 90\% acetone solution for $16 \mathrm{~h}$ to determine the quantity of extractives (TAPPI T-280 pm-99 method). Extractives-free bark was hydrolysed with $72 \%$ sulfuric acid at $30^{\circ} \mathrm{C}$ for $1 \mathrm{~h}(300 \mathrm{mg}$ of sample and $3 \mathrm{~mL}$ of sulfuric acid). The acid was diluted to $4 \%$ (adding $84 \mathrm{~mL}$ of water) and the mixture was heated at $121^{\circ} \mathrm{C}(1 \mathrm{~atm})$ for $1 \mathrm{~h}$. The residual material was cooled and filtered through porous glass filter number 4 . The solids were dried to constant weight at $105^{\circ} \mathrm{C}$ and determined as insoluble lignin according to the TAPPI standard (T222 om-02, 2006). The soluble lignin concentration in the filtrate was determined by the measurement of the absorbance at $205 \mathrm{~nm}$ and using the value of $110 \mathrm{~L} / \mathrm{g} \mathrm{cm}$ as the absorption coefficient. The concentration of monomeric sugars in the soluble fraction was determined by highperformance liquid chromatography (HPLC) (Merck Hitachi, Germany); column BIO-RAD HPX- $87 \mathrm{H}$ at $45^{\circ} \mathrm{C}$, eluted at $0.6 \mathrm{~mL} / \mathrm{min}$ with $5 \mathrm{mM} \mathrm{H}_{2} \mathrm{SO}_{4}$ using a refraction index detector at $30^{\circ} \mathrm{C}$. Glucose, xylose and mannan were used as external calibration standards. The glucans content was calculated by multiplying the glucose content by 0.9 ; the xylan/mannan content obtained from the xylose/ mannose content multiplied by 0.88 (Mendonça et al., 2008). All samples were analysed in triplicate.

\subsection{Neutral sulphite semi-chemical pulping of E. globulus bark}

Neutral sulphite semi-chemical pulping (NSSC) was carried out using a rotating digester equipped with four independent vessels of 1.2-liter capacity, $100 \mathrm{~g}$ of E. globulus bark (dry basis) and $500 \mathrm{~g}$ of liquor. For the screening-type experimental design, the charge of $\mathrm{Na}_{2} \mathrm{SO}_{3}$ varied between $5 \%$ to $16 \%$, and the sodium carbonate $\left(\mathrm{Na}_{2} \mathrm{CO}_{3}\right)$ charge, between $2 \%$ to $4 \%$. The reactor heating rate was $2.1^{\circ} \mathrm{C} / \mathrm{min}$ from room temperature and the cooking temperature was $160^{\circ} \mathrm{C}$ and $170^{\circ} \mathrm{C}$. After each reaction, the black liquor was drained, and pulps were washed with water at $50{ }^{\circ} \mathrm{C}$ until neutralise the $\mathrm{pH}$ of the liquor and thereby ensure the remotion of carbonates and sulphites from the pulp. Pulp yield was measured using the weight of the washed material. Cooked material was defibrated using a 12" laboratory single disc refiner, the pulp was defibrated making pass 3 times the 
material through the refiner, with disc opening of $0.02 \mathrm{~mm}$. The consistency of defibration varied between $4 \%$ in the first past until $2 \%$ in the last. Defibration yield was measured after refining and screening of the cooked material. Samples were stored for the chemical characterization and for the elaboration of liner papers.

\subsection{Bark pulps morphological properties}

Fibre morphological properties such as, length and fines content of bark pulps were determined by a Fiber Tester apparatus (Lorentzen \& Wettre, Sweden), where a $100 \mathrm{mg}$ sample was previously disintegrated in $100 \mathrm{~mL}$ distilled water for 10 minutes. During the analysis, the equipment measured approximately 35000 fibres of each sample. The samples were evaluated in triplicate.

\subsection{Paper sheets making}

Sets of ten paper sheets were made with pulps obtained from NSSC pulping experiments. The paper sheets were prepared according to the TAPPI standard (T205 sp-02, 2002) to obtain grammages of $100 \mathrm{~g} / \mathrm{m}^{2}$. The formation of the paper sheets was carried out in a sheet former (Regmed, Brasil). All paper sheets were dried for 5 hours at room temperature and then were conditioned to $50 \%$ relative humidity and $23^{\circ} \mathrm{C}$ for at least 8 hours. After conditioning, the dry weight of all the elaborated paper sheets was determined.

\subsection{Paper sheets mechanical properties}

Ten paper sheets were made for each experiment of the NSSC pulping and their mechanical properties were measured using TAPPI standard methods. The tensile properties of papers were determined according to T494 om-01 (2001); the bursting properties of papers were determined according to T403 om-02 (2002); the internal tearing resistance of papers were evaluated according to T414 om-04 (2004); the flat crush of corrugating medium properties (CMT test) of papers were determined according to T809 om-99 (1999); and the ring crush of paperboard properties (RCT test) of papers were evaluated according to T818 om-97 (1997).

\section{RESULTS AND DISCUSSION}

\subsection{Chemical characterization of E. globulus bark}

The chemical composition of the E. globulus bark used in this research is detailed in Table 1 . The main component found was glucans with $39.9 \%$, followed by xylan/mannan with $23.0 \%$ and lignin with $21.0 \%$. In relation to the content of glucans, differences in the total content are observed when compared with another research. Neiva et al. (2018) reported a glucan content of $37.5 \%$, while that Miranda et al. (2012) reported 56\%. This difference can be explained by the variations of the growth sites and the ages of the trees evaluated. Lignin content of $21 \%$ is slightly similar if it is compared with the research reported by Neiva et al. (2018) and by Fernandes et al. (2014), who reported values of $21.9 \%$ and $21.4 \%$, respectively. Bark is usually rich in extractives -including organic solvent and watersoluble- and polyphenolics. The extractive content was $6.4 \%$, which is consistent with results obtained by Neiva et al. (2018), who extracted with water, and Miranda et al. (2012), who reported an extractive content of 5.3\% using a polar solvent. The bark may contain a significant percentage of ash and alkali-soluble extractives (Miranda et al., 2012) that were not determined, which is expressed in Table 1 as other components. This percentage may vary between $5 \%$ and $6 \%$ for E. globulus bark, as described by Neiva et al. (2018).

Table 1. Eucalyptus globulus bark chemical composition.

$\begin{array}{ccccc}\text { Component } & \text { Miranda, 2012 } & \text { Fernández, 2014 } & \text { Neiva, 2018 } & \text { This work } \\ \text { Extractives, \% } & 5.3 & 4.3 & 6.4 & 21.9 \\ \text { Lignin, \% } & 16.9 & 21.4 & 37.5 & 21.0 \\ \text { Glucans, \% } & 56.0 & 41.0 & 13.5 & 23.6 \\ \text { Xylan/mannan, \% } & 23.7 & 19.8 & 10.4 & 23.0 \\ \text { Other, \% } & - & & 9.7\end{array}$

\subsection{Pulp characterization}

NSSC was performed on E. globulus bark at two different temperatures $\left(160^{\circ} \mathrm{C}\right.$ and $\left.170^{\circ} \mathrm{C}\right)$ and in two concentrations of sodium carbonate ( $2 \%$ and $4 \%$ ). Both variable conditions were studied with a variation of the sulphite concentration $(5 \%, 8 \%, 12 \%$ and $16 \%)$. The results of these experiments are shown in Tables 2 and 3. The pulp yield (pulp basis) 
obtained in the NSSC with $2 \%$ of carbonate is in the range of $\sim 53 \%-63 \%$ (Table 2), while for pulps obtained with $4 \%$ of carbonate is between $\sim 52 \%-61 \%$ (Table 3 ). The changes obtained in pulp yield are due to the sulphite concentration, which favours higher solubilization of lignin and hemicellulose fractions (Reyes et al., 2015). The yields obtained from bark pulps are lower than those obtained for semi-chemical pulps produced from wood, which yield 70\%-90\% (Pereira et al., 2011). However, the results showed are higher than those obtained by Neiva et al. (2016) and by Miranda et al. (2012), who used a kraft process in E. globulus bark and reported yields of $42 \%$ and $47 \%$, respectively. The yields in the kraft process are lower than the sulphite processes, mainly because it is intended that the lignin is low enough to allow the separation of the fibre (Sixta, 2006).

The difference in the yield of different pulps studied could be explained by the anatomical difference and chemical characteristics of the two types of raw materials (Neiva et al., 2014). The pulping process could be affected by the loss of small parenchyma cells and phloem vessels during pulping. It is important to consider that the phloem cells in E. globulus bark are estimated to be 50\% in volume. These cells could be easily degraded during pulping and thus could migrate with the effluent in the washing process (Neiva et al., 2016). The description of the anatomical characterization is supported by Quilhó et al. (2000), who determined that the type of parenchymal cells correspond to the main type of bark cell of E. globulus, which contributes to $50 \%$ by volume, followed by $28 \%$ of fibres. Moreover, chemically the bark has less hemicelluloses as reported by Neiva et al. (2014), which produces a reduction in fibrillation. As reported in the literature, the higher the hemicelluloses content, fibrillation capacity of cellulosic fibres it is easier (Iwamoto et al., 2008; Chaker et al., 2013).

Table 2. Pulp yield and chemical composition of pulp obtained from E. globulus bark with $2 \%$ of calcium carbonate.

\begin{tabular}{|c|c|c|c|c|c|c|c|}
\hline $\begin{array}{c}\text { Temperature, } \\
{ }^{\circ} \mathrm{C}\end{array}$ & $\begin{array}{c}\text { Sulphite, } \\
\%\end{array}$ & $\begin{array}{c}\text { Refined } \\
\text { pulp yield, } \\
\%\end{array}$ & $\begin{array}{c}\text { Cellulose } \\
\text { (glucans), } \\
\%\end{array}$ & $\begin{array}{c}\text { Hemicellulose } \\
\text { (xylan/mannan), } \\
\%\end{array}$ & $\begin{array}{c}\text { Acid soluble } \\
\text { Lignin, } \\
\%\end{array}$ & $\begin{array}{c}\text { Acid insoluble } \\
\text { Lignin, } \\
\%\end{array}$ & $\begin{array}{c}\text { Total lignin, } \\
\%\end{array}$ \\
\hline & & \multicolumn{6}{|c|}{ Calcium carbonate concentration, $2 \% \mathrm{w} / \mathrm{v}$} \\
\hline \multirow{4}{*}{160} & 5 & 61.7 & 43.6 & 11.2 & 1.3 & 15.8 & 17.1 \\
\hline & 8 & 58.7 & 42.9 & 10.5 & 1.0 & 14.2 & 15.2 \\
\hline & 12 & 56.5 & 42.1 & 9.1 & 1.3 & 11.8 & 13.1 \\
\hline & 16 & 53.9 & 41.7 & 8.8 & 1.0 & 10.4 & 11.4 \\
\hline \multirow{4}{*}{170} & 5 & 63.1 & 43.8 & 9.2 & 1.3 & 14.4 & 15.7 \\
\hline & 8 & 59.5 & 41.7 & 9.0 & 1.4 & 11.9 & 13.3 \\
\hline & 12 & 53.5 & 39.7 & 8.1 & 1.5 & 10.9 & 12.4 \\
\hline & 16 & 51.2 & 38.6 & 7.7 & 0.9 & 10.6 & 11.5 \\
\hline
\end{tabular}

Table 3. Pulp yield and chemical composition of pulp obtained from E. globulus bark with $4 \%$ of calcium carbonate.

\begin{tabular}{|c|c|c|c|c|c|c|c|}
\hline $\begin{array}{c}\text { Temperature, } \\
{ }^{\circ} \mathrm{C}\end{array}$ & $\begin{array}{c}\text { Sulphite, } \\
\%\end{array}$ & $\begin{array}{c}\text { Refined } \\
\text { pulp yield, } \\
\% \\
\end{array}$ & $\begin{array}{c}\text { Cellulose } \\
\text { (glucans), } \\
\% \\
\end{array}$ & $\begin{array}{c}\text { Hemicellulose } \\
\text { (xylan/ mannan), } \\
\%\end{array}$ & $\begin{array}{c}\text { Acid soluble } \\
\text { Lignin, } \\
\% \\
\end{array}$ & $\begin{array}{c}\text { Acid insoluble } \\
\text { Lignin, } \\
\% \\
\end{array}$ & $\begin{array}{c}\text { Total lignin, } \\
\%\end{array}$ \\
\hline & & \multicolumn{6}{|c|}{ Calcium carbonate concentration, $4 \% \mathrm{w} / \mathrm{v}$} \\
\hline \multirow{4}{*}{160} & 5 & 60.5 & 48.8 & 13.6 & 1.7 & 13.1 & 14.8 \\
\hline & 8 & 59.8 & 46.0 & 12.9 & 1.5 & 12.4 & 13.9 \\
\hline & 12 & 57.1 & 44.5 & 11.2 & 1.3 & 10.7 & 12.0 \\
\hline & 16 & 54.4 & 42.3 & 9.8 & 1.4 & 9.9 & 11.3 \\
\hline \multirow{4}{*}{170} & 5 & 60.8 & 46.9 & 13.0 & 1.9 & 15.2 & 17.1 \\
\hline & 8 & 56.8 & 44.1 & 12.1 & 1.8 & 13.5 & 15.3 \\
\hline & 12 & 54.6 & 43.5 & 10.7 & 1.1 & 12.2 & 13.3 \\
\hline & 16 & 51.8 & 42.3 & 9.2 & 1.3 & 10.9 & 12.2 \\
\hline
\end{tabular}

Concerning the chemical composition of the pulp, it is observed that the content of glucans varied from 38.6 to $48.8 \mathrm{~g}$ glucan $/ 100 \mathrm{~g}$, where the higher concentration is presented when the reaction conditions are less severe $\left(160{ }^{\circ} \mathrm{C}, 5 \%\right.$ of sulphite and $4 \%$ of carbonate) (Table 3 ).
As shown in Tables 2 and 3, it is possible to observe that there is a decrease in the glucan contents at higher sulphite charge. For lignin, the concentration varied from $11 \%$ to $17 \%$. The lower concentration of lignin (11.3\%) was obtained using $160{ }^{\circ} \mathrm{C}, 16 \%$ of sulphite and $4 \%$ of carbonate (Table 3 ). 
In contrast, the higher lignin content (17.1\%) resulted using $160{ }^{\circ} \mathrm{C}, 5 \%$ of sulphite, and $2 \%$ of carbonate (Table 2 ). The xylan/mannan (hemicelluloses) content varied from $7.7 \%$ to $13.6 \%$, where the higher concentrations resulted using $4 \%$ of carbonate (13\%-13.6\%) (Table 3 ), and the lowest concentration was obtained using $2 \%$ of carbonate (7.7\%) (Table 2). Considering the chemical characterization of bark pulp, it is possible to determine the importance of the neutralizing agent, which with a dosage of $4 \%$ is able to maintain a high yield of glucans, xylan, and mannan in the pulp due to its ability to neutralize acidic agents that could disintegrate cellulosic material. This observation is supported by the research carried out by Ahmadi et al. (2010), who reported the use of the sodium carbonate as neutralizing agent at a concentration of $4 \%$ recommended to neutralize the reaction and to stabilize the cellulose structure in an NSSC pulping.

As observed in Tables 2 and 3, the sum of the percentages of glucans, xylan/mannan, and lignin, in addition to the cells lost by washing, there is a remaining fraction, which is not addressed on these tables. Such a relevant fraction should be expressed by the presence of extractive components and inorganic compounds. The bark, unlike the wood, contains much more extractives and ashes. Most of the bark extractives are similar to those contained in wood, however, the polyphenols and suberins contained in the extractives from bark are of higher molecular weight. Among these polyphenols, tannins can be found. These tannins could cause problems in the paper manufacture, in the equipment, and therefore in the physical-mechanical properties of the sheets themselves. In addition, the presence of extractives could generate problems such as: staining, resin, and undesired precipitations (Dutt and Tyagi, 2011; Miranda et al., 2012; Neiva et al., 2018). The amount of extractives can be dissolved using a neutral sulphite process (Young, 1994; Vásquez et al., 2008).

At the morphological level is observed that the stage of refining causes a decrease in the average fibre length in approximately $30 \%$, going from $1.058 \mathrm{~mm}$ average in fibre without treatment to $0.73 \mathrm{~mm}$ in fibre treated with $2 \%$ of carbonate, $5 \%$ of sulphite at $160{ }^{\circ} \mathrm{C}$, and to $0.76 \mathrm{~mm}$ in fibre treated with $2 \%$ of carbonate, $16 \%$ of sulphite at $170{ }^{\circ} \mathrm{C}$. The concentration of fines increases in comparison with untreated fibres going from $4.8 \%$ to $5.6 \%$ and $5.8 \%$ average for pulp obtained at $160^{\circ} \mathrm{C}$ and $170{ }^{\circ} \mathrm{C}$, respectively.

One point to take in consideration in the refining stage of the NSSC pulping is the type of raw material that is introduced into the equipment. In all circumstances, it is important that the material introduced between the refining discs is uniformed in size, water content, and in its composition (Mokvist and Johansen, 1993). Therefore, the use of bark in the refiner should not cause a greater deterioration than regular use.

\subsection{Paper sheets mechanical properties}

The strength properties of the paper sheets elaborated with the pulps obtained from NSSC process are presented in Figure 1.
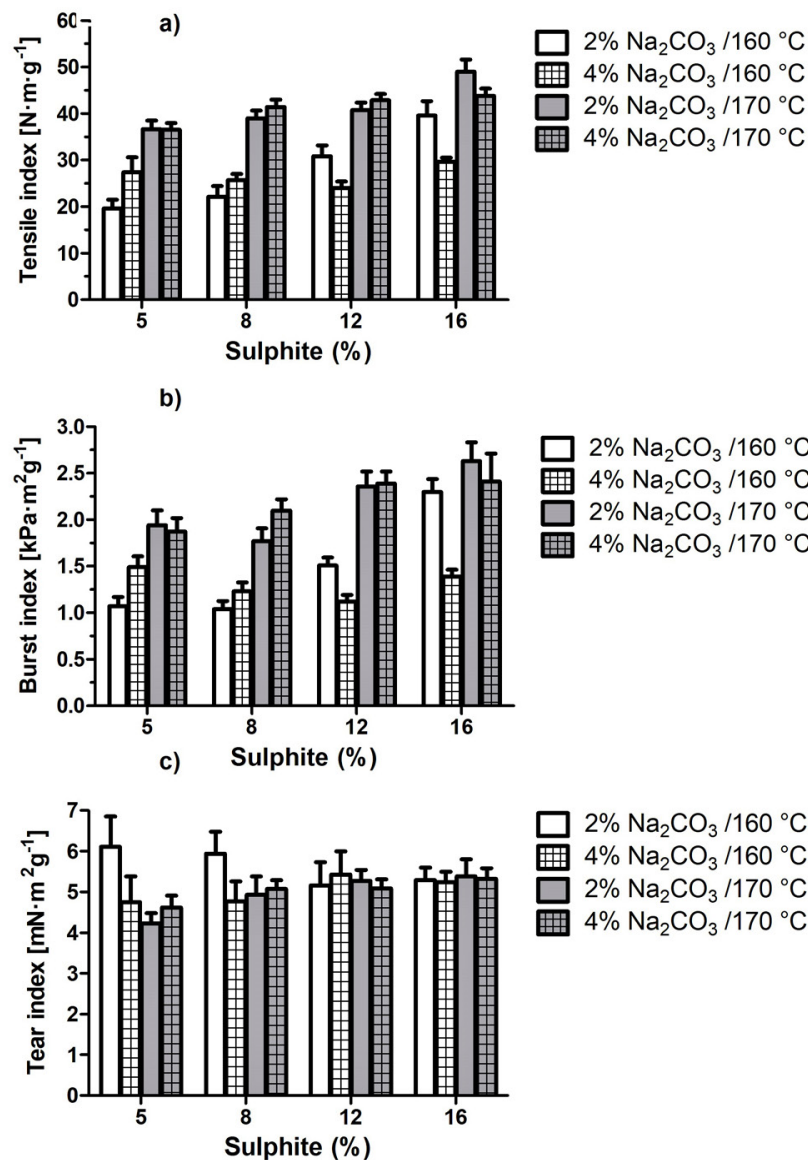

Figure 1. Strength properties of paper sheets prepared from E. globulus bark pulps using $2 \%$ and $4 \%$ of sodium carbonate at $160^{\circ} \mathrm{C}$ and $170^{\circ} \mathrm{C}$ in different sulphite concentration: (a) tensile index, (b) burst index, (c) tear index.

It is observed that the tensile index improved when the pulps were produced at $170{ }^{\circ} \mathrm{C}$ and $16 \%$ of sulphite resulting in $49 \mathrm{Nm} / \mathrm{g}$ and $44 \mathrm{Nm} / \mathrm{g}$ using $2 \%$ and $4 \%$ of carbonate, respectively as shown in Figure 1a. These results are higher than those reported by Fica (2015) regarding the recycled paper, where a highest tensile strength value of $38 \mathrm{Nm} / \mathrm{g}$ was obtained. However, a lower resistance is observed compared to paper sheets made from Eucalyptus nitens wood pulp using an NSSC process with values above $50 \mathrm{Nm} / \mathrm{g}$ at 170 ${ }^{\circ} \mathrm{C}$ and $15 \%$ of sulphite as described by Pereira et al. (2005). 
This result can be explained by the differences in the average lengths of the fibres. The fibres from pulps obtained in this research at $170{ }^{\circ} \mathrm{C}$ using $2 \%$ of carbonate, with $12 \%$ and $16 \%$ of sulphite show average of fibre lengths of $0.78 \mathrm{~mm}$ and $0.76 \mathrm{~mm}$, respectively. This result is similar as reported by Pirralho et al. (2014) who described fibre lengths of $0.72 \mathrm{~mm}$ from E. globulus wood. Morphological properties of fibres such as length and width could be considered critical properties to achieve efficient fibre-fibre bonding. Nevertheless, the large proportion of parenchyma cell and vessels probably play a role in the behavior of the bark pulps (Fernandes et al., 2014).

The burst index showed good results in pulps obtained at $170^{\circ} \mathrm{C}$ as shown in Figure $1 \mathrm{~b}$. It was observed that as the sulphite concentration increases, the burst resistance rates are higher using a lower amount of carbonate. In contrast, when there is an increase in carbonate, only at higher temperatures does an upward trend follow, since at $160^{\circ} \mathrm{C}$ the burst rate remains constant. With $2 \%$ of carbonate, the best burst indexes values were achieved in pulps at $170{ }^{\circ} \mathrm{C}$ using $12 \%$ and $16 \%$ of sulphite resulting in 2.4 and $2.6 \mathrm{kPam}^{2} / \mathrm{g}$, respectively. With $4 \%$ of carbonate, the higher burst indexes were obtained in pulps processed at $170{ }^{\circ} \mathrm{C}$ with sulphite concentrations of $8 \%, 12 \%$, and $16 \%$, which resulted in values of $2.1,2.4$, and $2.4 \mathrm{kPam}^{2} / \mathrm{g}$, respectively. These burst indexes are consistent and slightly higher than those described by Rudi et al. (2016) who reported values between 1.7 to $2.1 \mathrm{kPam}^{2} / \mathrm{g}$ using an NSSC pulp on sunflower stalk. However, these values are lower when compared to the burst resistance reported by Pereira et al. (2005) who reported a value of $2.9 \mathrm{kPam}^{2} / \mathrm{g}$ using NSSC pulp on E. nitens wood.

As shown in Figure 1c, tear resistance of pulps obtained at $170{ }^{\circ} \mathrm{C}$ increased with the sulphite concentration, while the opposite effect was observed when the temperature was $160{ }^{\circ} \mathrm{C}$. For pulps with $2 \%$ of carbonate, the tear rates had two high values at each temperature with opposite sulphite concentration: at $160{ }^{\circ} \mathrm{C}$ with $5 \%$ sulphite, a tear index of $6.1 \mathrm{mNm}^{2} / \mathrm{g}$ was obtained and $5.38 \mathrm{mNm}^{2} / \mathrm{g}$ at $170{ }^{\circ} \mathrm{C}$ with $16 \%$ of sulphite. With $4 \%$ of carbonate, there were no significant differences in the results for both temperatures, being the higher values of $5.4 \mathrm{mNm}^{2} / \mathrm{g}$ at $160{ }^{\circ} \mathrm{C}$ and $12 \%$ of sulphite, and $5.3 \mathrm{mNm}^{2} / \mathrm{g}$ at $170{ }^{\circ} \mathrm{C}$ and $16 \%$ of sulphite. The tear index values obtained in this research are similar in comparison to those reported by Fernandes et al. (2014) who show a tear index value of $5.0 \mathrm{mNm}^{2} / \mathrm{g}$ using pulp from E. globulus bark.

The tear index has correlation with the chemical characterization of bark pulp. An NSSC less severe facilitates the highest tear index in comparison with an NSSC with the lowest temperature and sulphite concentration that have a higher quantity of lignin and hemicelluloses. This allows a structure more stable, with higher strength and rigid properties to the tear tests. Tear indexes are lower using higher sulphite concentration with a low quantity of lignin (11.5\%) in the NSSC process. A small quantity of lignin and hemicelluloses allows a more rigid cellulosecellulose bond. This phenomenon is consistent with that reported by Reyes et al. (2015), where the tear index in correlation to the decreasing of lignin and hemicellulose concentrations is discussed when the reaction conditions of the chemithermomechanical pulping mechanism are more severe using wood from $P$. radiata.

Figure 2 ( $\mathrm{a}$ and $\mathrm{b}$ ) shows CMT and RCT results, respectively. The NSSC pulps are considered optimal for preparing corrugated cartons due to their great stiffness (Casey, 1980; Cathie \& Guest, 2001), resulting from their lignin content and the higher amount of hemicelluloses. The paper sheets tested by CMT shows a higher performance at the highest reaction temperature and sulphite concentrations. The results obtained with $4 \%$ of carbonate at $160^{\circ} \mathrm{C}$ do not vary significantly when the sulphite concentration increases. The higher CMT values were $1.61 \mathrm{Nm}^{2} / \mathrm{g}$ and $1.63 \mathrm{Nm}^{2} / \mathrm{g}$, obtained with $2 \%$ of carbonate at $170{ }^{\circ} \mathrm{C}$ using $12 \%$ and $16 \%$ of sulphite, respectively. According to the CMT index, the results shown in this research, present lower values than those reported by other authors such as Kasmani et al. (2014) in pulp from the mixing of the old corrugated container with virgin neutral sulphite semi-chemical pulp, where it was obtained a value of $2.73 \mathrm{Nm}^{2} / \mathrm{g}$.

The RCT test depends on the force and pressure applied on the edge of the carton along the cylinder axis. The result is usually proportional to the CMT results (Casey, 1980). The paper sheets tested by RCT showed a higher result at the highest reaction temperature $\left(170^{\circ} \mathrm{C}\right)$ and at higher concentrations of sulphite as is shown in Figure $2 \mathrm{~b}$. The results obtained with $4 \%$ of carbonate at $160{ }^{\circ} \mathrm{C}$ showed a slight decrease in the property of RCT at higher concentrations of sulphite. The higher RCT values were obtained with $2 \%$ of carbonate at $170^{\circ} \mathrm{C}$ : $1.66 \mathrm{Nm}^{2} / \mathrm{g}$ and $1.74 \mathrm{Nm}^{2} / \mathrm{g}$ using $12 \%$ and $16 \%$ sulphite, respectively. In contrast, at $160^{\circ} \mathrm{C}$ the higher value found was $1.54 \mathrm{Nm}^{2} / \mathrm{g}$ with $12 \%$ of sulphite. The results shown for RCT tests were higher when comparing them to those reported by Kasmani et al. (2014) where a higher value of $1.13 \mathrm{Nm} / \mathrm{g}$ was obtained in sulphite pulp obtained from old corrugated pulp with virgin fibres. 

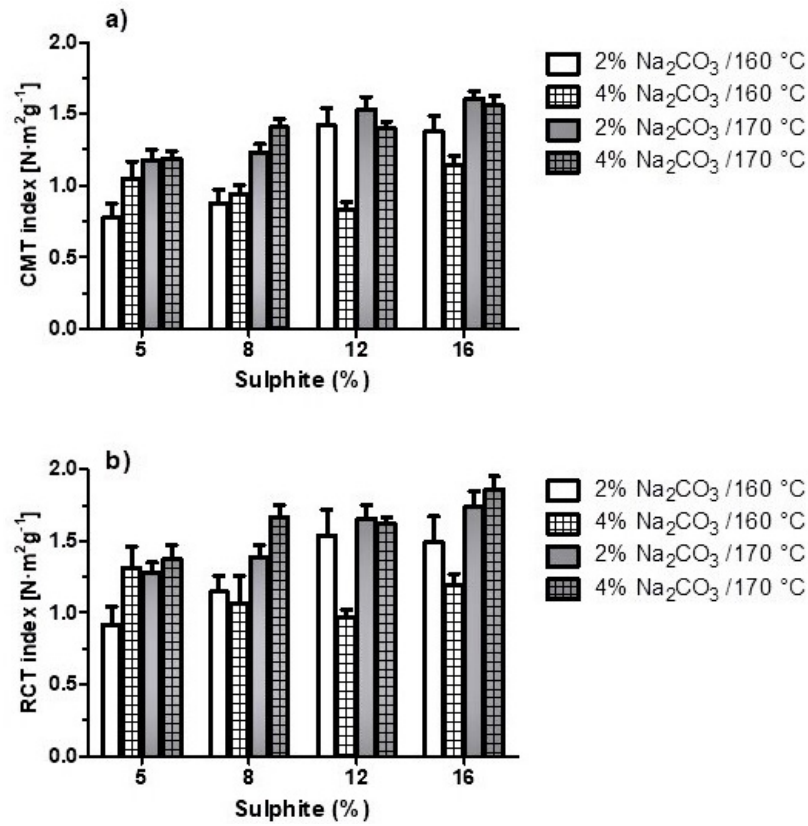

Figure 2. CMT (a), and RCT (b) properties of paper sheets produced from E. globulus bark pulps elaborated using $2 \%$ and $4 \%$ of sodium carbonate at $160^{\circ} \mathrm{C}$ and $170^{\circ} \mathrm{C}$ in different sulphite concentration.

\section{CONCLUSIONS}

Eucalyptus globulus bark has a high content of cellulose and hemicellulose with ratios that are slightly lower than in wood of E. globulus, which makes it an interesting raw material for the pulp industry, as an alternative fibre. The NSSC pulping is effective in getting pulp with high yield and good chemical characteristics. The conditions researched showed that $170^{\circ} \mathrm{C}, 2 \%$ of sodium carbonate, and $16 \%$ of sulphite are the best conditions to obtain higher mechanical performance of paper sheets. The properties of hand sheets produced under this condition are suitable to produce linerpaper with similar values to those offered in the market for recycled paper (testliner), providing advantages with the use of virgin fibres compared to the recycled fibres. $E$. globulus bark would have the potential to be used in the liner paper industry.

\section{ACKNOWLEDGMENTS}

This research was conducted with the support provided by the Innovation Fund for Competitiveness of the Chilean Economic Development Agency (CORFO) under Grant no. 13CEI2-21839. A. Andrade thanks to National Agency for Research and Development (ANID)/Scholarship program (Doctoral grant No 220-21202153).

\section{SUBMISSION STATUS}

Received: 17 Jul. 2020

Accepted: 22 Feb. 2021

Associate editor: Fernando Gomes

\section{CORRESPONDENCE TO}

\section{Francisco Vásquez-Garay}

Centro de Excelencia en Nanotecnología (CEN), Av. Román Díaz 532, Providencia, Santiago, Chile.

e-mail: fvasquez@leitat.cl

\section{REFERENCES}

Ahmadi M, Latibari AJ, Faezipour M, Hedjazi S. Neutral sulphite semi-chemical pulping of rapeseed residues. TÜBITAK 2009; 34 : 11-16. Doi: 10.3906/tar-0903-19.

Bajpai P. Chapter 12 - Pulping Fundamentals. In: Bajpai, P. B. T.-B. H. of P. and P. Third E. (ed.). Elsevier; 2018.

Cathie K, Guest D. Guide to Waste paper, S.A. Mirshokraei (tr), Aejj Press, Tehran; 2001.

Casey P. Pulp and Paper Chemistry Technology, Vol. 1. John Wiley and Sons, New York; 1980.

Chaker A, Alila S, Mutjé P, Vilar MR, Boufi S. Key role of the hemicellulose content and the cell morphology on the nanofibrillation effectiveness of cellulose pulps. Cellulose 2013: 20(6): 2863-2875. Doi: 10.1007/s10570-013-0036-y.

Dutt D, Tyagi CH. Comparison of various eucalyptus species for their morphological, chemical, pulp and paper making characteristics. Indian Journal of Chemical Technology 2011: 18: 145-151.

Eugenio MA, Ibarra D, Martín-Sampedro R, Espinosa E, Bascón I, Rodríguez A. Alternative raw materials for pulp and paper production in the concept of a lignocellulosic biorefinery. 2019. Doi: 10.5772/intechopen.90041.

Fernandes L, Neiva D, Amaral ME, Gominho J, Pereira H, Duarte AP, Simões R. Papermaking potential of wood and pre-hydrolyzed bark of Eucalyptus globulus. Conference: EWPL, Sevilla, Spain; 2014.

Fica A. Obtención de celulosa nanofibrilada (CNF) a partir de los finos generados durante el reciclado de papel (tesis). Facultad de Ingeniería, Departamento de Ingeniería Química, Universidad de Concepción, Chile; 2015.

Iwamoto S, Abe K, Yano H. The effect of hemicelluloses on wood pulp nanofibrillation and nanofiber network characteristics. Biomacromolecules 2008: 9(3): 1022-1026. Doi: 10.1021/bm701157n.

Kasmani JE, Samariha A, Nemati M. Effect of Mixing Different Contents of OCC Pulp on NSSC Pulp Strength. BioResources 2014: 9(3): 5480-5487. Doi: 10.15376/biores.9.3.5480-5487.

Le Normand M, Edlund U, Ek M. Spruce bark hemicelluloses and pectins extraction and characterization. In: Proceedings of the $16^{\text {th }}$ ISWFPC, June 8-10 Tiajin, China; 2011.

Lima MA, Lavorente GB, da Silva H, Bragatto J, Rezende CA, Bernardinelli OD et al. Effects of pretreatment on morphology, chemical composition and enzymatic digestability of eucalyptus 
bark: a potentially valuable source of fermentable sugars for biofuel production - part 1. Biotechnology for Biofuels 2013: 75(6). Doi: 10.1186/1754-6834-6-75.

Małachowska E, Lipkiewicz A, Niemczyk M, Dubowik M, Boruszewski P, Przybysz P. Influences of fiber and pulp properties on papermaking ability of cellulosic pulps produced from alternative fibrous raw materials. Journal of Natural Fibers 2019. Doi: 10.1080/15440478.2019.1697994.

Matsushita Y, Yamauchi K, Takabe K, Awano T, Yoshinaga A, Kato M, Kobayashi T. Enzymatic saccharification of Eucalyptus bark using hydrothermal pre-treatment with carbon dioxide. Bioresource Technology 2010: 101: 4936-4939. Doi: 10.1016/ j.biortech.2009.09.041.

Mendonça RT, Jara JF, Gonzalez V, Elissetche JP, Freer J. Evaluation of white root fungi Ganoderma australe and Ceriporiopsis subvermispora in biotechnological applications. Journal of Industrial Microbiology and Biotechnology 2008: 35: 1323-1330. Doi: 10.1007/s10295-008-0414-x.

Miranda I, Gominho J, Pereira H. Incorporation of bark and tops in Eucalyptus globulus wood pulping. BioResources 2012: 7(3): 4350-4361. Doi: 10.15376/biores.7.3.4350-4361.

Miranda I, Gominho J, Mirra I, Pereira H. Fractioning and chemical characterization of barks of Betula pendula and Eucalyptus globulus. Industrial Crops and Products 2013: 41: 299-305. Doi: 10.1016/ j.indcrop.2012.04.024.

Mokvist A, Johansen T. Refiner with means to protect the refining discs from premature wear. U.S. Patent No. 5203514. Washington, DC: U.S. Patent and Trademark Office 1993. Available from: https:// patents.justia.com/patent/5203514.

Monsalve E, Pereira M, Borquez R, Berg A. Recuperación de Reactivos y Sustancias Orgánicas de Alto Peso Molecular en el Pulpaje Semiquímico al Sulfito Neutro Mediante Ultrafiltración. ATCP Chile 2010: 26 (2): 25.

Neiva DM, Gominho J, Pereira H. Modeling and optimization of Eucalyptus globulus bark and wood delignification using response surface methodology. BioResources 2014: 9(2): 2907-2921. Doi: 10.15376/biores.9.2.2907-2921

Neiva DM, Gominho J, Fernandes L, Lourenço A, Chemetova C, Simões RMS, Pereira $\mathrm{H}$. The potential of hydrothermally pretreated industrial barks from E. globulus as a feedstock for pulp production. Journal of Wood Chemistry and Technology 2016: 36: 383-392. Doi: 10.1080/02773813.2016.1184280.

Neiva DM, Araújo S, Gominho J, de Cássia Carneiro A, Pereira H. Potential of Eucalyptus globulus industrial bark as a biorefinery feedstock: Chemical and fuel characterization. Industrial Crops and Products 2018: 123: 262-270. Doi: 10.1016/j.indcrop.2018.06.070.

Oficina de Estudios y Políticas Agrarias (ODEPA). Estudio de caracterización de la cadena de producción y comercialización de la industria forestal: Estructura, agentes y prácticas. Santiago, Chile; 2016. Available from: https://www.odepa.gob.cl/wp-content/ uploads/2017/12/InformeIndustriaForestal2016.pdf.

Oveissi F, Sitter T, Fatehi P. PDADMAC as a flocculant for lignosulfonate of NSSC pulping process. Biotechnology Progress 2016: 32(3): 686-691. Doi: 10.1002/btpr.2251.
Pereira M, Melo R, Pereira C. Pulpaje Semiquímico de Eucaliptus (Eucaliptus nitens ex maideni). 2nd International Colloquium on Eucaliptus Kraft Pulp. Concepción, Chile; 2005.

Pereira MA, Patt R, Kordsashia O. Efecto de la carga de Sulfito de Sodio en el Pulpaje NSSC de E. globulus. Madera, Ciencia y Tecnologia 2011: 13(2): 225-234. Doi: 10.4067/S0718-221X2011000200010.

Pirralho M, Flores D, Sousa VB, Quilhó T, Knapic S, Pereira H. Evaluation on paper making potential of nine Eucalyptus species based on wood anatomical features. Industrial Crops and Products 2014: 54: 327-334. Doi: 10.1016/j.indcrop.2014.01.040.

Quilhó T, Pereira H, Richter GH. Within-Tree variation in phloem cell dimensions and proportion in Eucalyptus globulus. IAWA Journal 2000: 21(1): 31-40. Doi: 10.1163/22941932-90000234.

Rahmaninia M, Khosravani A. Improving the paper recycling process of old corrugated container wastes. Cellulose Chemistry and Technology 2015: 49: 203-208.

Reyes P, Ferraz A, Pereira M, Rodríguez J, Teixeira Mendonça R. Chemithermomechanical and kraft pulping of Pinus radiata wood chips after the hydrothermal extraction of hemicelluloses. Holzforschung 2015: 69(1): 33-40. Doi: 10.1515/hf-2013-0235.

Romani A, Larramendi A, Yañez R, Cancela A, Sánchez A, Teixeira JA, Domingues L. Valorization of Eucalyptus nitens bark by organosolv pretreatment for the production of advanced biofuels. Industrial Crops and Products 2019: 132: 327-335. Doi: 10.1016/ j.indcrop.2019.02.040.

Rudi H, Resalati H, Eshkiki RB, Kermanian H. Sunflower stalk neutral sulfite semi-chemical pulp: an alternative fiber source for production on fluting paper. Journal of Cleaner Production 2016: 127: 562-566. Doi: 10.1016/j.jclepro.2016.04.049.

Sartori C, da Silva Mota G, Ferreira J, Miranda I, Mori AF, Pereira $\mathrm{H}$. Chemical characterization of the bark of Eucalyptus urophylla hybrids in view of their valorization in biorefineries. Holzforschung 2016: 70(9): 819-828. Doi: 10.1515/hf-2015-0258.

Santos S, Villaverde JJ, Silva CM, Neto CP, Silvestre A. Supercritical fluid extraction of phenolic compounds from Eucalyptus globulus Labill bark. The Journal of Supercritical Fluids 2012: 71: 71-79. Doi: 10.1016/j.supflu.2012.07.004.

Sillero L, Prado R, Andrés MA, Labidi J. Characterization of bark of six species from mixed Atlantic forest. Industrial Crops and Products 2019: 137: 276-284. Doi: 10.1016/j.indcrop.2019.05.033.

Sixta, Herbert (ed.). Handbook of pulp. Wiley-vch, 2006.

TAPPI standard T 280 mm-99 (1999) "Acetone extractives of wood and pulp”, Tappi Press, Atlanta, G.A.;1999.

TAPPI standard T 222 om-02 (2006) "Acid-insoluble lignin in wood and pulp”, Tappi Press, Atlanta, G.A.; 2006.

TAPPI standard T 205 sp-02 (2002) "Forming handsheets for physical tests of pulp”, Tappi Press, Atlanta, G.A.; 2002.

TAPPI standard T 494 om-01 (2001) “Tensile breaking properties of paper and paperboard”, Tappi Press, Atlanta, G.A.; 2001.

TAPPI standard T 403 om-02 (2002) "Bursting strength of paper", Tappi Press, Atlanta, G.A.; 2002.

TAPPI standard T 414 om-04 (2004) "Internal tearing resistance of paper”, Tappi Press, Atlanta, G.A.;2004. 
TAPPI standard T 809 om-99 (1999) "Flat crush of corrugating medium (CMT test)”, Tappi Press, Atlanta, G.A.; 1999.

TAPPI standard T $818 \mathrm{~cm}-97$ (1997) "Ring crush of paperboard (RCT test)”, Tappi Press, Atlanta, G.A.;1997.

Vázquez G, Fontenla E., Santos J, Freire MS, González-Álvarez J, Antorrena G. Antioxidant activity and phenolic content of chestnut (Castanea sativa) shell and eucalyptus (Eucalyptus globulus) bark extracts. Industrial crops and products 2008: 28(3): 279-285. Doi: 10.1016/j.indcrop.2008.03.003.

Yang X, Berglund LA. Recycling without fiber degradation-strong paper structures for 3D forming based on nanostructurally tailored wood holocellulose fibers. ACS Sustainable Chemistry and Engineering 2020: 8: 1146-1154. Doi: 10.1021/acssuschemeng.9b06176.

Young RA. Comparison of the properties of chemical cellulose pulps. Cellulose 1994: 1(2): 107-130. Doi: 10.1007/BF00819662. 